\title{
Ascorbic acid deficiency in guinea pigs: contrasting effects of tissue ascorbic acid depletion and of associated inanition on status indices related to collagen and vitamin $D$
}

\author{
BY HARUMI TSUCHIYA* AND C. J. BATES $\dagger$ \\ MRC Dunn Nutrition Unit, Milton Road, Cambridge CB4 IXJ
}

(Received 15 September 1993 - Revised 9 February 1994-Accepted 2 March 1994)

\begin{abstract}
To investigate the sensitivity of guinea pig tissues to ascorbic acid depletion, as distinct from inanition, young male guinea pigs were maintained with either ascorbic acid restriction or total diet restriction for 8 weeks. One group (A) received no ascorbic acid for 3 weeks, then $0.5 \mathrm{mg} / \mathrm{d}$ for 5 weeks; one group (B) was weight-matched by restricted food intake to the first group; a third (marginally deficient) group (C) received $1 \mathrm{mg}$ ascorbic acid/d throughout; a fourth was weight-matched to this group (D); and a fifth group received the control diet $a d l i b$. (E). Both of the groups with restricted ascorbic acid intakes (A and C) developed very low tissue ascorbic acid contents, but only the first group (severely deficient group A) also exhibited a severely reduced growth rate. This group also exhibited reduced femur calcium and hydroxyproline contents and reduced skin hydroxyproline content. These changes were not seen in the corresponding weight-matched group (B). Neither plasma alkaline phosphatase (EC 3.1.3.1) activity, nor a variety of indices of vitamin $D$ status exhibited changes which conld be attributed specifically to reduced ascorbic acid intake and hence to lowered tissue ascorbic acid content. It is concluded that low tissue ascorbic acid levels in guinea pigs clearly alter the connective tissue composition of growing femur and skin, but do not necessarily produce a major, specific effect on vitamin D status. Moreover, the control of inanition is crucial to permit interpretation of the changes in metabolism that are caused by ascorbic acid deficiency.
\end{abstract}

Ascorbic acid: Guinea pig: Vitamin D

The sensitivity of bone connective tissue to the effect of ascorbic acid deficiency in ascorbicacid-requiring species such as the guinea pig and higher primates, including man, is well established. Earlier studies from this laboratory (Bates, 1979) showed that bone collagen synthesis, measured by the incorporation of labelled proline into collagen hydroxyproline, was second only to skin collagen synthesis in its sensitivity to ascorbic acid depletion in the guinea pig. It was also apparent that inanition, which typically accompanies ascorbic acid deficiency in guinea pigs, may exert secondary effects on metabolic processes which are not attributable to the lowered tissue ascorbic acid levels per se. It is therefore important to distinguish the non-specific effects of inanition from the specific effects of tissue ascorbic acid depletion.

Recently a study was reported (Sergeev et al. 1990) suggesting that vitamin D metabolism may also be sensitive to ascorbic acid deficiency in guinea pigs, and that the consequent alterations in hormonal control of calcium may be responsible for some of the bone defects seen in ascorbic-acid-deficient animals. However, this study did not include inanition controls, and did not report growth curves; thus it was unclear whether the reported effects were specific for ascorbic acid depletion, or secondary to inanition. In addition, Weiser et

* On leave of absence from Bunka Women's University, 3-22-1 Yoyogi, Shibuya-ku, Tokyo 151, Japan.

$\dagger$ For reprints. 
al. (1991) in a brief report suggested that chicks fed on diets containing ascorbic acid supplements exhibited raised plasma 1,25-dihydroxycholecalciferol and duodenal calciumbinding protein levels, and increased bone strength.

The purpose of the present study was to examine the effects of ascorbic acid deficiency in guinea pigs on selected indices of bone connective tissue development, and to compare the effects of ascorbic acid deficiency with those of growth retardation produced by general restriction of food intake.

\section{MATERIALS AND METHODS}

Purified guinea pig diet contained the following components $(\mathrm{g} / \mathrm{kg})$ : sucrose 103 , glucose 78 , maize starch 200 , purified casein 300 , cellulose powder 150 , maize oil 73 , potassium acetate 25 , choline chloride 2 , salt mixture 60 , vitamin mixture $2, \mathrm{MgO} 5$, inositol 2 . The salt mix was that of Greenfield et al. (1969) plus sodium hydrogen selenite, $0.6 \mathrm{mg} / \mathrm{kg}$ diet and potassium chromate, $33 \mathrm{mg} / \mathrm{kg}$ diet. The vitamin mixture provided the following amounts $(\mathrm{mg} / \mathrm{kg} \mathrm{diet})$ : retinol 2.4 as retinyl acetate, cholecalciferol $0.0075, \alpha$-tocopherol 60 , menadione 10 , thiamin 16 , riboflavin 16 , pyridoxine 16 , calcium pantothenate 40 , nicotinamide 200 , pteroylmonoglutamic acid 10 , cyanocobalamin 0.05 and biotin 1.2 . To this was added ascorbic acid, $2 \mathrm{~g} / \mathrm{kg}$ diet for the control groups only. All animals received a small handful of dried autoclaved hay each day and drinking water ad lib. They were housed singly in wire cages, with a $12 \mathrm{~h}$ light-dark cycle.

Forty-nine young male Dunkin-Hartley guinea pigs with a mean body weight of $257 \mathrm{~g}$ were divided into five weight-matched groups as follows:

A ( $n$ 17): no ascorbic acid for 3 weeks, then $0.5 \mathrm{mg} / \mathrm{d}$ for 5 weeks, given by oral dosing. B ( $n$ 8): control diet ( $2 \mathrm{~g}$ ascorbic acid $/ \mathrm{kg}$ diet); body weights matched to group $\mathrm{A}$ (group-matching by food restriction).

$\mathrm{C}(n \mathrm{8}): \quad 1 \mathrm{mg}$ ascorbic acid/d by oral dosing throughout.

$\mathrm{D}(n \mathrm{8})$ : control diet; body weights group-matched to those of group C.

$\mathrm{E}(n$ 8): control diet $a d$ lib.

After 8 weeks on these regimens the animals were killed by $\mathrm{CO}_{2}$ anaesthesia, and their blood and organs were removed for analysis.

\section{Analytical methods}

Vitamin C (ascorbic + dehydroascorbic acids) was measured in extracts of adrenals and spleen. The freshly excised organs were homogenized (Potter-Elvehjem homogenizer) with 10 volumes of metaphosphoric acid $(50 \mathrm{~g} / \mathrm{l})$ and centrifuged. Supernatant fractions were analysed on a Cobas Bio centrifugal analyser, by the method of Vuilleumier \& Keck (1989), based on ascorbate oxidase $(E C$ 1 10.3.3) treatment followed by orthophenylene diaminecoupling.

Alkaline phosphatase (EC 3.1.3.1) was measured in (heparinized) plasma, by the method of Levine (1974), adapted for the Cobas Bio analyser.

$\mathrm{Ca}$, total hydroxyproline and total amino- $\mathrm{N}$ were measured in bone. Femurs (one per animal) were dissected free of adventitious tissue, and were dissolved in about $12 \mathrm{ml} 6 \mathrm{M}$ $\mathrm{HCl}$ by heating at $100^{\circ}$ for $24 \mathrm{~h}$. The resulting solution was partly neutralized by adding $12 \mathrm{ml} \mathrm{1.2} \mathrm{M-NaOH}$, then diluted 1:200 with water, and the Ca content was measured by the dye-interaction method of Gindler \& King (1972), adapted to the Cobas Bio centrifugal analyser (Roche Kit No. 0770612: Unikit II Calcium MTB). Total plasma Ca was measured by the same kit procedure. Total hydroxyproline was measured by the method of Ho \& Pang (1989) on the $6 \mathrm{M}-\mathrm{HCl}$ bone hydrolysates after 1:1000 dilution in water. Total amino-N was measured by an automated version of the method of Goodwin (1968). 
Hydroxyproline and total amino- $\mathrm{N}$ were measured in dorsal skin. A $49 \mathrm{~mm}^{2}$ circle of skin was removed from the pelt in the dorsal scapular region and was cleared of subcutaneous fat and of hair by scraping. It was hydrolysed in $5 \mathrm{ml} 6 \mathrm{M}-\mathrm{HCl}$ as above, diluted, and the total hydroxyproline and total amino- $\mathrm{N}$ contents were measured as for bone.

25-Hydroxycholecalciferol and 1,25-dihydroxycholecalciferol were measured in plasma, by the methods of Hollis \& Napoli (1985) and of Hollis (1986) respectively, using Incstar kits, cat. 58100 and 60065 (Incstar Corporation, Stillwater, MN, USA).

Kidney 25-hydroxycholecalciferol-1-hydroxylase (EC 1.14.13.13) activity was measured by a technique adapted from the methods of Fraser \& Kodicek $(1970,1973)$ and Henry \& Norman (1974). Kidneys were homogenized (Potter-Elvehjem homogenizer) in 7 volumes

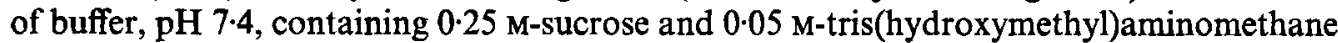
chloride. Mitochondria from $0.05 \mathrm{~g}$ kidney and an $850 \mathrm{~g}$ supernatant preparation from $0.025 \mathrm{~g}$ kidney were incubated in $1.525 \mathrm{ml}$ total volume, at $37^{\circ}$, shaken in an $\mathrm{O}_{2}$ atmosphere for $0 \mathrm{~min}$ (zero time) and $60 \mathrm{~min}$, with the following final concentrations: $\mathrm{MgCl}_{2}, 16 \mathrm{mM}$; oxidized NADP, $0.2 \mathrm{~mm}$; reduced NADP, $0.2 \mathrm{mM}$; glucose 6-phosphate, $3.9 \mathrm{mM}$; glucose6-phosphate dehydrogenase (EC 1.1.1.49), 0.46 units/ml; L-malate, $9.8 \mathrm{~mm}$; unlabelled 25-hydroxycholecalciferol $1.0 \mu \mathrm{M}$ and $\left.26,27{ }^{3} \mathrm{H}\right]$-25-hydroxycholecalciferol (Amersham International, UK, catalogue no. TRK 396), $1.5 \mathrm{kBq}$. Following the incubation the reaction was stopped with $1.5 \mathrm{ml}$ acetonitrile and the insoluble proteins were removed by

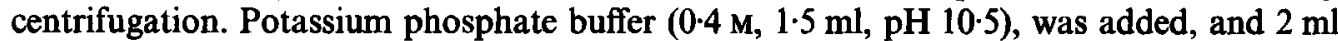
portions of the soluble fraction were analysed by chromatography on Analytichem $\mathrm{C}_{18} \mathrm{OH}$ (Technicol, Cheshire) as described by Hollis (1986). After elution with water and methanol-water $(70: 30, \mathrm{v} / \mathrm{v}), 25$-hydroxycholecalciferol was eluted with methylene dichloride in hexane $(100 \mathrm{ml} / 1)$. Following an intermediate fraction (2-propanol in hexane, $10 \mathrm{ml} / 1), 1,25$-dihydroxycholecalciferol was eluted with 2-propanol in hexane $(35 \mathrm{ml} / \mathrm{l})$. The separation efficiency was verified by checking that samples of authentic labelled 25 . hydroxy- and 1,25-dihydroxycholecalciferol (Incstar) were eluted, as predicted, almost entirely in the third and fifth fractions respectively. Hydroxylase activities $(\mu \mathrm{mol}$ per incubation) were calculated from the percentage conversion of labelled substrate to the dihydroxy derivative.

Intergroup differences were tested by one-way ANOVA followed by the Scheffé test, or by Students' $t$ test when comparing two groups only.

\section{RESULTS}

Table 1 shows the final body weights and body-weight changes over the last 2 weeks of the study. Whereas the ad-lib.-fed control group (E) increased in its mean body weight from 257 to $656 \mathrm{~g}$ during the entire 8-week period of the experiment, group A, which was moderately to severely deficient in ascorbic acid, increased only to $421 \mathrm{~g}$ by the end of the 8 -week period, despite receiving $0.5 \mathrm{mg}$ ascorbic acid/d for the last 5 weeks. Group B, which was weight-matched to A, needed to be given less food than was apparently consumed by group A (measurements of food intake may have been biased slightly by spillage). Group $C$, the mildly deficient group, which received $1 \mathrm{mg}$ ascorbic acid/d throughout the study, maintained a growth weight which was very similar to that of the ad lib. control group $\mathrm{E}$ for most of the study.

The concentration of ascorbic acid in two tissues which typically concentrate the vitamin to a high level, namely adrenals and spleen, are shown in Table 1. Both of the ascorbic-acidrestricted groups (A and $C$ ) exhibited reduced tissue ascorbic acid concentrations in comparison with the three control groups (B, D and E) which in turn did not differ greatly from each other, despite large differences in food intake and in growth rates between group 
Table 1. Growth, and organ vitamin $C$ (ascorbate and dehydroascorbate) concentrations in guinea pigs fed on diets deficient or marginally deficient in ascorbic acid, compared with controls*

(Mean values with their standard errors for seventeen animals in group A and eight animals in each of the other four groups)

\begin{tabular}{|c|c|c|c|c|c|c|c|c|c|}
\hline \multirow[b]{2}{*}{ Group } & \multirow[b]{2}{*}{ Description } & \multicolumn{2}{|c|}{$\begin{array}{l}\text { Final body } \\
\text { weight } \\
\text { (g) }\end{array}$} & \multicolumn{2}{|c|}{$\begin{array}{l}\text { Weeks } 6-8: \\
\text { body-weight } \\
\text { change }(g)\end{array}$} & \multicolumn{2}{|c|}{$\begin{array}{c}\text { Adrenal vitamin } \\
\underset{(\mu \mathrm{mol} / \mathrm{g})}{\dagger}\end{array}$} & \multicolumn{2}{|c|}{$\begin{array}{c}\text { Spleen vitamin } \\
\text { C† } \\
(\mu \mathrm{mol} / \mathrm{g})\end{array}$} \\
\hline & & Mean & SE & Mean & SE & Mean & SE & Mean & $\mathrm{SE}$ \\
\hline $\mathbf{A}$ & Deficient & $421^{\mathrm{a}}$ & 18 & $-21 \cdot 4^{\mathrm{a}}$ & $14 \cdot 7$ & $0 \cdot 14^{a}$ & 0.023 & $0.021^{\mathrm{a}}$ & 0.003 \\
\hline B & $\begin{array}{l}\text { Weight-matched } \\
\text { to group } \mathbf{A}\end{array}$ & $418^{\mathrm{a}}$ & 15 & $-22 \cdot 4^{\mathrm{a}}$ & 3.9 & $7 \cdot 07^{\mathrm{b}}$ & $0 \cdot 76$ & $2 \cdot 06^{b}$ & 0.20 \\
\hline$C$ & $\begin{array}{c}\text { Marginally } \\
\text { deficient }\end{array}$ & $649^{b}$ & 10 & $+31 \cdot 4^{b}$ & $5 \cdot 9$ & $0.32^{\mathrm{a}}$ & 0.067 & $0.063^{\mathrm{a}}$ & 0.009 \\
\hline $\mathrm{D}$ & $\begin{array}{l}\text { Weight-matched } \\
\text { to group C }\end{array}$ & $650^{\mathrm{b}}$ & 15 & $+37 \cdot 1^{\mathrm{b}}$ & 4.8 & $9 \cdot 75^{\mathrm{b}}$ & 0.66 & $1.93^{\mathrm{b}}$ & 0.28 \\
\hline $\mathbf{E}$ & $\begin{array}{l}\text { Ad-lib.fed } \\
\text { controls }\end{array}$ & $656^{b}$ & 27 & $+48 \cdot 8^{b}$ & $11 \cdot 1$ & $11 \cdot 01^{b}$ & $1 \cdot 17$ & $2 \cdot 26^{b}$ & 0.14 \\
\hline
\end{tabular}

a, b Mean values within each column bearing different superscript letters were significantly different $(P<0.001)$ by the Scheffé test following one-way ANOVA. Groups A and C differed by Student's $t$ test $(P<0.05)$ in their adrenal and spleen vitamin $C$ concentrations.

* For details of diets and procedures, see pp. 746-747.

$\dagger$ The precision estimate (within-run) of the vitamin $\mathbf{C}$ assay, expressed as the coefficient of variation of duplicates, was $3 \%$.

$\mathrm{B}$ on one hand and groups $\mathrm{D}$ and $\mathrm{E}$ on the other. The striking difference in growth rate between groups $\mathrm{A}$ and $\mathrm{C}$ was accompanied by only a moderate difference in their tissue ascorbic acid levels. Group A had relatively enlarged adrenals and spleens in comparison with body weights (not shown), which is a well-established and characteristic feature of ascorbic acid deficiency.

Accompanying the lowered ascorbic acid concentration and growth rates in group $A$ was a clear reduction in bone $\mathrm{Ca}$ and bone hydroxyproline concentrations, per unit of bone weight (Table 2). The change in hydroxyproline was not shared by group B and was not, therefore, a secondary result of the inanition occurring in group $\mathrm{A}$; for $\mathrm{Ca}$ the weightmatched group (B) had an intermediate result, so that an inanition effect could not be ruled out. The change in $\mathrm{Ca}$ was not observed in the more mildly deficient animals in group $\mathrm{C}$. The hydroxyproline: total amino- $\mathrm{N}$ ratio in bone (not shown) was significantly depressed in group A $(P<0.001$, by Students' $t$ test, $v$. groups B or E). Skin hydroxyproline per unit area was very considerably reduced in group $A$ (Table 2 ) but was less markedly reduced in group B (compared with groups C, D and E). On a skin-weight basis the hydroxyproline content was reduced in group A (not shown), and on a total amino-N basis it was not significantly reduced in any of the diet-restricted groups (not shown).

Plasma Ca levels were, as expected, unaffected by the different dietary treatments (Table 2), but plasma alkaline phosphatase activity, which reflects bone Ca metabolism, was reduced in both groups A and B. This effect was exhibited in equal measure by both the groups which were growing slowly or losing weight, regardless of whether the cause was vitamin $\mathrm{C}$ restriction or total food restriction. The fact that this enzyme activity was reduced, not increased, in the ascorbic-acid-deficient animals, argues against the existence of functional vitamin D deficiency. 
Table 2. Concentrations of bone calcium, bone and skin hydroxyproline and plasma calcium, and plasma alkaline phosphatase (EC 3.1.3.1) activity in guinea pigs fed on diets deficient or marginally deficient in ascorbic acid, compared with controls*

(Mean values with their standard errors for seventeen animals in group $\mathbf{A}$ and eight animals in each of the other four groups)

\begin{tabular}{|c|c|c|c|c|c|c|c|c|c|c|c|}
\hline \multirow[b]{2}{*}{ Group } & \multirow[b]{2}{*}{ Description } & \multicolumn{2}{|c|}{$\begin{array}{c}\text { Bone Ca } \\
\text { (mmol } / \mathrm{g} \\
\text { bone) }\end{array}$} & \multicolumn{2}{|c|}{$\begin{array}{c}\text { Bone } \\
\text { hydroxyproline } \dagger \\
(\mu \mathrm{mol} / \mathrm{g} \text { bone })\end{array}$} & \multicolumn{2}{|c|}{$\begin{array}{c}\text { Skin } \\
\text { hydroxyproline } \dagger \\
\left(\mu \mathrm{mol} / \mathrm{cm}^{2}\right)\end{array}$} & \multicolumn{2}{|c|}{$\begin{array}{c}\text { Plasma } \\
\text { Cat† } \\
(\mathrm{mmol} / \mathrm{l})\end{array}$} & \multicolumn{2}{|c|}{$\begin{array}{c}\text { Plasma alkaline } \\
\text { phosphatase }+\dagger \dagger \\
(\mathrm{U} / 1)\end{array}$} \\
\hline & & Mean & $\mathbf{S E}$ & Mean & $\mathbf{S E}$ & Mean & SE & Mean & SE & Mean & $\mathbf{S E}$ \\
\hline $\mathbf{A}$ & Deficient & $2 \cdot 27^{\mathrm{a}}$ & 0.092 & $78 \cdot 0^{\mathrm{a}}$ & 3.6 & $22 \cdot 2^{\mathrm{a}}$ & 0.92 & $2 \cdot 53^{8}$ & 0.08 & $68 \cdot 3^{2}$ & $6 \cdot 7$ \\
\hline $\mathbf{B}$ & $\begin{array}{l}\text { Weight-matched } \\
\text { to group A }\end{array}$ & $2 \cdot 67^{\mathrm{ab}}$ & 0.045 & $107 \cdot 2^{b}$ & $2 \cdot 7$ & $33 \cdot 1^{b}$ & 0.76 & $2 \cdot 31^{4}$ & 0.13 & $68 \cdot 1^{\mathrm{a}}$ & 7.6 \\
\hline C & $\begin{array}{c}\text { Marginally } \\
\text { deficient }\end{array}$ & $2 \cdot 77^{b}$ & 0-087 & $115.9^{b}$ & $1 \cdot 2$ & $41 \cdot 5^{e}$ & 1.98 & $2 \cdot 59^{\mathrm{a}}$ & 0.08 & $103 \cdot 2^{\mathrm{ab}}$ & $9 \cdot 0$ \\
\hline $\mathbf{D}$ & $\begin{array}{l}\text { Weight-matched } \\
\text { to group C }\end{array}$ & $2 \cdot 77^{b}$ & 0.087 & $110 \cdot 4^{b}$ & $3 \cdot 1$ & $44 \cdot 3^{c}$ & $2 \cdot 44$ & $2 \cdot 40^{\mathrm{s}}$ & 0.09 & $84 \cdot 0^{\mathrm{ab}}$ & $7 \cdot 4$ \\
\hline $\mathrm{E}$ & $\begin{array}{l}A d \text {-lib.-fed } \\
\text { controls }\end{array}$ & $2 \cdot 65^{\mathrm{ab}}$ & 0.65 & $107 \cdot 7^{\mathrm{b}}$ & $2 \cdot 2$ & $43 \cdot 0^{c}$ & $1 \cdot 22$ & $2 \cdot 64^{\mathrm{s}}$ & 0.13 & $110 \cdot 3^{b}$ & $4 \cdot 2$ \\
\hline
\end{tabular}

a, b, c Mean values within a column bearing different superscript letters were significantly different $(P<0.05)$ by the Scheffé test, following one-way ANOVA. By Student's $t$ test, the significance of the difference between groups $A$ and $B$ for bone calcium was $P<0.005$, and that for bone hydroxyproline was $P<0.001$. Between groups B and $C$ for plasma alkaline phosphatase, it was $P<0.001$.

* For details of diets and procedures, see pp. 746-747.

Precision estimates (within-run) of the assays, expressed as coefficients of variation of duplicates were: $\uparrow 2 \cdot 1 \%$, $++0.8 \%,++1.9 \%$.

Table 3. Plasma 25-hydroxy- and 1,25-dihydroxycholecalciferol concentrations, and kidney 1-hydroxylase (EC 1.14.13.13) activity in guinea pigs fed on diets deficient or marginally deficient in ascorbic acid, compared with controls $\dagger$

(Mean values with their standard errors for seventeen animals in group A and eight animals in each of the other four groups)

\begin{tabular}{|c|c|c|c|c|c|c|c|}
\hline \multirow[b]{2}{*}{ Group } & \multirow[b]{2}{*}{ Description } & \multicolumn{2}{|c|}{$\begin{array}{c}\text { Plasma } \\
\text { 25-hydroxycholecalciferol } \ddagger \\
(\mathrm{nmol} / \mathrm{l})\end{array}$} & \multicolumn{2}{|c|}{$\begin{array}{c}\text { Plasma } \\
\text { 1,25-dihydroxycholecalciferol\$ } \\
\text { (pmol/1) }\end{array}$} & \multicolumn{2}{|c|}{$\begin{array}{c}\text { Kidney } \\
\text { 1-hydroxylase } \\
\text { activity\|l } \\
\text { (nmol converted) }\end{array}$} \\
\hline & & Mean & $\mathrm{SE}$ & Mean & SE & Mean & SE \\
\hline A & Deficient & $17 \cdot 6^{*}$ & 1.7 & $18 \cdot 7$ & $7 \cdot 4$ & 0.12 & 0.020 \\
\hline B & $\begin{array}{l}\text { Weight-matched } \\
\text { to group A }\end{array}$ & $27 \cdot 2$ & $3 \cdot 6$ & $12 \cdot 3$ & $4 \cdot 6$ & $0 \cdot 16$ & 0.040 \\
\hline $\mathbf{C}$ & $\begin{array}{l}\text { Marginally } \\
\text { deficient }\end{array}$ & $19 \cdot 5$ & $1 \cdot 1$ & $41 \cdot 1$ & $19 \cdot 2$ & 0.20 & 0.029 \\
\hline D & $\begin{array}{l}\text { Weight-matched } \\
\text { to group C }\end{array}$ & $26 \cdot 4$ & $4 \cdot 1$ & $10 \cdot 6$ & $3 \cdot 1$ & $0 \cdot 16$ & 0.012 \\
\hline $\mathbf{E}$ & $\begin{array}{l}\text { Ad-lib.-fed } \\
\text { controls }\end{array}$ & $20 \cdot 5$ & $2 \cdot 2$ & $36 \cdot 5$ & $12 \cdot 2$ & 0.17 & 0.020 \\
\hline
\end{tabular}

Mean value was significantly different from that for group B by Student's $t$ test: ${ }^{*} P<0.05$.

$\dagger$ For details of diets and procedures, see pp. 746-747.

Precision estimates (within-run), expressed as coefficients of variation of duplicates, were $\ddagger 7.0 \%, \S 9 \cdot 5 \%$, || $6.0 \%$. 
Table 3 shows the effects of ascorbic acid restriction and inanition on the two major vitamin D metabolites, 25-hydroxycholecalciferol and 1,25-dihydroxycholecalciferol, in plasma, and the apparent activity of kidney 25-hydroxycholecalciferol-1-hydroxylase in kidney mitochondrial preparations. For plasma 25-hydroxycholecalciferol there was a marginally significant ( $t$ test $P<0.05$ ) difference between groups $\mathrm{A}$ and $\mathrm{B}$; group $\mathrm{E}$ had intermediate values. Inanition may thus increase levels of this metabolite, whereas low ascorbic acid intakes may produce the opposite effect, but neither influence was very striking in the present study. In the case of 1,25-dihydroxycholecalciferol, inanition in groups $\mathrm{B}$ and $\mathrm{D}$ reduced the levels in comparison with group $\mathrm{E}$, and when expressed on a $\log$ scale, groups B and D both differed from group E by Students' $t$ test $(P<0.05)$. However, there was no clear-cut effect of ascorbic acid deficiency, independent from that of inanition. The kidney 1-hydroxylase assay (Table 3) did not reveal a clear-cut effect of either ascorbic acid deficiency or inanition.

\section{DISCUSSION}

The growth curves and tissue ascorbic acid levels seen in the present study illustrate clearly the fact that near-normal growth can be achieved in young male guinea pigs when they receive daily intakes of $1 \mathrm{mg}$ ascorbic acid (the ad lib. control group $\mathrm{E}$ was by comparison receiving a mean daily intake of $60 \mathrm{mg}$ ascorbic acid), despite enormous differences in the tissue ascorbic acid contents between groups $\mathrm{C}$ and $\mathrm{E}$. Nevertheless, a further reduction in ascorbic acid intake, to $0.5 \mathrm{mg} / \mathrm{d}$ in group $\mathrm{A}$, produced a major reduction in growth rate, despite only a modest further reduction in tissue ascorbic acid levels. A previous estimate (Ginter et al. 1968, 1979) of the minimum daily requirement for optimal growth of guinea pigs was about $0.5 \mathrm{mg} / \mathrm{d}$; this was in a different strain of guinea pig and with a different basal diet.

Of the two ascorbic-acid-restricted groups, only group A exhibited significant reductions in femur $\mathrm{Ca}$ and hydroxyproline levels, and these were attributable specifically to lowered tissue ascorbic acid levels, as distinct from the effects of inanition and of reduced growth. It is likely that ascorbate deprivation results both in reduced growth in length, and in osteopenia (which results in the changes in calcium and hydroxyproline per unit mass). It was not the purpose of the present study to distinguish and separate these alternatives. Likewise, the detailed dissection of ascorbic acid deprivation effects on collagenous $v$. noncollagenous proteins was not the subject of the present study, in which the findings are generally consistent with the conclusion that collagenous proteins are more sensitive than non-collagenous proteins to this particular nutritional insult (Barnes \& Kodicek, 1972).

Group A also exhibited a very marked reduction in skin hydroxyproline (i.e. collagen) content, whereas group B exhibited a smaller reduction in collagen content, which was significant only per unit area of skin, not per unit wet weight or per unit of total amino-N.

In contrast with these skin and bone indices, plasma alkaline phosphatase was equally affected in both groups $A$ and $B$, indicating that inanition was the dominant influence in this case. Plasma 25-hydroxycholecalciferol and 1,25-dihydroxycholecalciferol were not dramatically affected either by ascorbic acid depletion or by inanition, although inanition may, of course, become a confounding factor, in severe scurvy. Our experience with the kidney 1-hydroxylase ( $E C$ 1.14.13.13) assay is compatible with the suggestion that the low conversion rates observed might be attributable to the presence of binding proteins for 25-hydroxycholecalciferol in the kidney homogenates (D. R. Fraser, personal communication), and it is recognized, moreover, that other vitamin $\mathrm{D}$ metabolites may co-migrate with 1,25-dihydroxycholecalciferol, which may further complicate the interpretation of this particular assay. 
Sergeev et al. (1990) reported a significant reduction in kidney 1-hydroxylase activity in scorbutic guinea pigs, but did not report growth curves or tissue ascorbic acid concentrations and did not include inanition controls. It is therefore unclear whether this reduction was specific for tissue ascorbate depletion. Other differences in their assay methodology included the use of renal cortex slices rather than isolated mitochondria, a higher concentration of 25 -hydroxycholecalciferol substrate $(4.3 \mu \mathrm{M})$ and a different method of separating the products of reaction, based on HPLC. Although observations from other studies (Turnbull \& Omaye, 1980; Bjorkhem et al. 1987; Crivello, 1988) have indicated possible mechanisms whereby tissue ascorbic acid depletion may affect steroid hydroxylations in ways which might also affect vitamin $D$ metabolite formation, the evidence that this actually occurs in vivo remains incomplete.

In the present study, major changes in bone connective tissue composition and major changes in growth rate in animals with moderately severe ascorbic acid restriction were not accompanied by ascorbic-acid-specific changes in plasma vitamin $\mathrm{D}$ metabolites. It thus appears most likely that the changes in skin and bone connective tissue composition were initiated by changes in collagen synthesis, consequent on reduced post-translational proline and lysine hydroxylation or by changes in collagen-specific messenger RNA and signalling mechanisms (Peterkofsky, 1991; Shapiro et al. 1991; Franceschi, 1992), as distinct from changes in Ca economy resulting from impaired vitamin $\mathrm{D}$ metabolism. Clearly the careful dissection of inanition-induced changes from those that can be attributed specifically to ascorbic acid restriction is a vital step in the better understanding of the specific metabolic roles of ascorbic acid in vivo.

Technical assistance by Mr A. Wayman is gratefully acknowledged. We are also indebted to F. Hoffmann-La Roche for a gift of unlabelled 25-hydroxycholecalciferol.

\section{REFERENCES}

Barnes, M. J. \& Kodicek, E. (1972). Biological hydroxylations and ascorbic acid with special regard to collagen metabolism. Vitamins and Hormones 30, 1-43.

Bates, C. J. (1979). Vitamin C deficiency in guinea pigs: variable sensitivity of collagen at different sites. International Journal of Vitamin and Nutrition Research 49, 77-86.

Bjorkhem, I., Kallner, A. \& Karlmar, H. E. (1987). Effects of ascorbic acid deficiency on adrenal mitochondrial hydroxylation in guinea pigs. Journal of Lipid Research 19, 695-704.

Crivello, J. P. (1988). Oxidative stress limits vitamin D metabolism by bovine proximal tubule cells in vitro. Archives of Biochemistry and Biophysics 262, 471-480.

Franceschi, R. T. (1992). The role of ascorbic acid in mesenchymal differentiation. Nutrition Reviews 50, 65-70.

Fraser, D. R. \& Kodicek, E. (1970). Unique biosynthesis by kidney of a biologically active vitamin D metabolite. Nature 228, 764-766.

Fraser, D. R. \& Kodicek, E. (1973). Regulation of 25-hydroxy-cholecalciferol-1-hydroxylase activity in kidney by parathyroid hormone. Nature New Biology 241, 163-166.

Gindler, E. M. \& King, J. D. (1972). Rapid colorimetric determination of calcium in biological fluids with methylthymol blue. American Journal of Clinical Pathology 58, 376-382.

Ginter, E., Bobek, P. \& Ovecka, M. (1968). Model of chronic hypovitaminosis C in guinea pigs. International Journal of Vitamin and Nutrition Research 38, 104-113.

Ginter, E., Bobek, P. \& Vargova, D. (1979). Tissue levels and optimum dosage of vitamin C in guinea pigs. Nutrition and Metabolism 23, 217-226.

Goodwin, J. F. (1968). The colorimetric estimation of plasma amino nitrogen with DNFB. Clinical Chemistry 14, 1080-1090.

Greenfield, H., Briggs, G. M., Watson, R. H. J. \& Yudkin, J. (1969). An improved diet for carbohydrate preference studies with rats: some criticisms of experimental diets. Proceedings of the Nutrition Society 28, $43 \mathrm{~A}$.

Henry, H. L. \& Norman, A. W. (1974). Studies on calciferol metabolism. IX. Renal 25-hydroxy-vitamin $D_{3}-1-$ hydroxylase. Involvement of cytochrome P-450 and other properties. Journal of Biological Chemistry 249 , 7529-7535.

Ho, K.-C. \& Pang, C. P. (1989). Automated analysis of urinary hydroxyproline. Clinica Chimica Acta 85, $191-195$.

Hollis, B. W. (1986). Assay of circulating 1,25-dihydroxy vitamin D involving a novel single cartridge extraction and purification procedure. Clinical Chemistry 32, 2060-2063. 
Hollis, B. W. \& Napoli, J. L. (1985). Improved radioimmunoassay for vitamin D and its use in assessing vitamin D status. Clinical Chemistry 31, 1815-1819.

Levine, J. B. (1974). Determination in blood with automated analysers. In Methods of Enzymatic Analysis, 2nd ed., vol. 2, pp. 856-870 [H. U. Bergmeyer, editor]. New York: Academic Press.

Peterkofsky, B. (1991). Ascorbate requirement for hydroxylation and secretion of pro-collagen: relationship to inhibition of collagen synthesis in scurvy. American Journal of Clinical Nutrition 54, 1135S-1140S.

Sergeev, I. N., Arkhapchev, Y. P. \& Spirichev, V. B. (1990). Ascorbic acid effects on vitamin D hormone metabolism and binding in guinea pigs. Journal of Nutrition 120, 1185-1190.

Shapiro, I. M., Leboy, P. S., Tokuoka, T., Forbes, E., DeBolt, K., Adams, S. L. \& Pacifici, M. (1991). Ascorbic acid regulates multiple metabolic activities of cartilage cells. American Journal of Clinical Nutrition 54, $1209 \mathrm{~S}-1213 \mathrm{~S}$.

Turnbull, J. D. \& Omaye, S. T. (1980). Synthesis of cytochrome P-450 heme in ascorbic acid deficient guinea pigs. Biochemical Pharmacology 29, 1255-1260.

Vuilleumier, J. P. \& Keck, E. (1989). Fluorimetric assay of vitamin C in biological materials using a centrifugal analyser with fluorescence attachment. Journal of Micronutrient Analysis 5, 25-34.

Weiser, J., Schlachter, M., Probst, H. P., Bachmann, H. \& Kormann, A.-W. (1991). Vitamin C optimises transformation of vitamin $\mathrm{D}_{3}, 1,25-(\mathrm{OH})_{3}-\mathrm{D}_{3}$ and bone metabolism in chicks. In Proceedings of the First International Conference on Vitamins and Biofactors in Life Sciences, Kobe, Japan, pp. 1223-1224 [T. Kobayashi, editor]. Tokyo: Centre for Academic Publications, Japan. 